\title{
ENVIRONMENTAL AND SPATIAL EFFECTS OF THE CONSTRUCTION OF OLSZTYN SOUTHERN BYPASS ROAD
}

\begin{abstract}
Jacek KIL, Department of Planning and Spatial Engineering, Faculty of Geodesy, Geospatial and Civil Engineering, University of Warmia and Mazury in Olsztyn, ul. R. Prawocheńskiego 15, 10-720 Olsztyn, Poland, jacek.kil@uwm.edu.pl (corresponding author) Marek SIEMIŃSKI, Department of Administration and Management, Faculty of Economics, University of Warmia and Mazury in Olsztyn, ul. R. Prawocheńskiego 3, 10-720 Olsztyn, Poland, markos@ uwm.edu.pl

This paper is an attempt to show what environmental and spatial consequences will be brought by the construction of the southern ring-road of Olsztyn, which is a linear investment. It also justifies the choice of the location from among four variants that were taken into consideration at the planning stage. The area in which the ring-road is located is characterised by particularly precious natural values due to the occurrence of rivers, lakes, diversified relief, rich flora and fauna or bird refuges. Many of these elements are covered by legal forms of natural protection. As a result of numerous discussions between planners, ecologists and the local community, the best variant of the course of the ring-road was chosen, which is the subject - matter of the analysis presented below.
\end{abstract}

Keywords: bypass road, protected areas, spatial effects, environmental conditions

\section{INTRODUCTION}

In the age of the increase of the number of vehicles and intense traffic, urban traffic systems often turn out to be maladjusted to quickly changing needs, particularly those concerning the handling of intense transit traffic. This creates the need to modernise the existing road infrastructure and to look for new ways of improving the traffic system. One of them is the construction of ring-roads.

The construction of city ring-roads is a serious planning challenge. Their presence becomes indispensable in the current urban and suburban space. A particularly important task of city ring-roads is to lead intense transit traffic outside the built-up urban area. This reduces not only the impact, particularly in the case of trucks, on the material tissue of cities, but also the impact of negative factors on the health of inhabitants. The risk of accidents, noise and pollutant emissions decreases, with the time of transport of goods becoming shorter. Unfortunately, investments of this kind need much space for their fulfilment. Their spatial expansiveness strongly affects the environment and the landscape and is a specific barrier to spatial planning and development. The planning and completion of ring-roads is a complex long-term process which often gives rise to social and spatial conflicts in areas through which it runs.

The problem of the construction of the ring-road applies also to Olsztyn - the capital of Warmia and Masuria. The proper location of the ring road is very important due to the proximity of the diversified and undevastated nature appreciated in terms of flora and fauna. In 2004, a new form of nature protection - the Natura 2000 Area - appeared in Polish legislation. The planned south-eastern section of Olsztyn's ring-road runs through the Special Bird Protection Area - Natura 2000 - the Napiwodzko-Ramucka Forest PLB280007, the Area of Protected Landscape of the Napiwodzko-Ramucka Forest and other valuable areas mentioned in the further part of the text.

\section{THE HISTORY OF OLSZTYN'S RING-ROAD}

Olsztyn is a dynamically developing city located in the north-eastern part of Poland. Before World War II, it also functioned as an important economic centre in East Prussia. Already at that time, German planners recognised the need of replacing the then-current traffic system with a more suitable system for big developing urban areas. They sketched potential possibilities of the location of Olsztyn's ring-road shortly behind facilities of contemporary Kortowo, i.e. south of the city.

Ring-road construction plans were resumed only in the 1970s, but construction works were regarded mainly as a defence requirement imposed by the army (Gwiaździńska-Goraj, 2011).

The problem was resumed again in the 1990s, when planning and design works concerning urban and regional traffic were undertaken. In the years 1999-2000, the first feasibility study was prepared in the Provincial Office for Spatial Planning 
with regard to the possibility of bypassing the city on routes between regional roads no. 16, 51 and 53, and the Olsztyn City prepared a city transport study. In both studies, the construction of Olsztyn's ring-road was taken into account (www.obwodnica.olsztyn.eu). In 2000, an agreement was signed between six communes for planners' co-operation in the designing of the course of the future ring-road of the city. The communes undertook to reserve relevant areas protecting the course of the route in Local Spatial Development Plans. In 2005, the General Directorate for National Roads and Motorways (GDDKiA) made a decision on the commencement of works on the ring-road project. In the years 2006-2007, GDDKiA prepared a multi-variant concept for the course of the ring-road; in 2007, the Ministry of Regional Development included the Olsztyn ring-road construction project on the indicative list of the Operational Program for the Development of Eastern Poland. The planned investment was also adopted by the resolution of the Council of Ministers for the National Road Construction Program for the years 2008-2012. Unfortunately, in 2010, the Ministry of Finance and the Ministry of Transport refused to grant funds for the partial financing of the ring-road construction project to GDDKiA. The years 2010-2013 are the period of intensive activity of the authorities and inhabitants of the city aimed at maintaining the construction of the southern ring-road of Olsztyn. Eventually, GDDKiA Division in Olsztyn announced tenders for the construction of two sections of the southern ring-road of Olsztyn in December 2013. Its construction will result in the change of the city transport system. In 2014, the Olsztyn City Office announced tenders for the design documentation of the construction and reconstruction of streets providing access to junctions of the ring-road.

\section{COURSE OF OLSZTYN'S SOUTHERN RING-ROAD}

The length of the planned southern ring-road of Olsztyn is $28 \mathrm{~km}$ (the main axis in the course of the National Road no. 16). Its beginning is located in the course of the National Road no. 16, in the section from the area of the Kudypy village west of Olsztyn, whereas its end is located in the area of the Wójtowo village east of the city. It is situated within the administrative borders of Gietrzwałd, Stawiguda, Purda and Barczewo communes and in the fragment of the Olsztyn city with county rights. It is a double-lane road, with two lanes in each direction. 6 road junctions, 36 road structures and 32 culverts will be built.

The initial section of the ring-road runs through a managed forest near the Kudypy village. Then it intersects the double-track railway line Olsztyn-Ostróda, and its further part to the Olsztyn Południe junction intersects a mosaic of arable lands, afforested field areas, small forest clusters, idle lands and loosely built-up areas. Then, running along arable lands, it intersects the railway line Olsztyn-Olsztynek and crosses the Lyna River after $12 \mathrm{~km}$. After around 14 $\mathrm{km}$, the road intersects the Natura 2000 PLB280007 - the Napiwodzko-Ramucka Forest. Then, running among arable lands, the road intersects the single-track railway line Olsztyn-Szczytno and reaches allotment gardens and a managed forest after $23 \mathrm{~km}$ of its course. The course of the road ends in the Barczewo commune among a mosaic of grasslands, bypassing the Wójtowo village on the south-eastern side and joining the National Road no. 16 (DK-16).

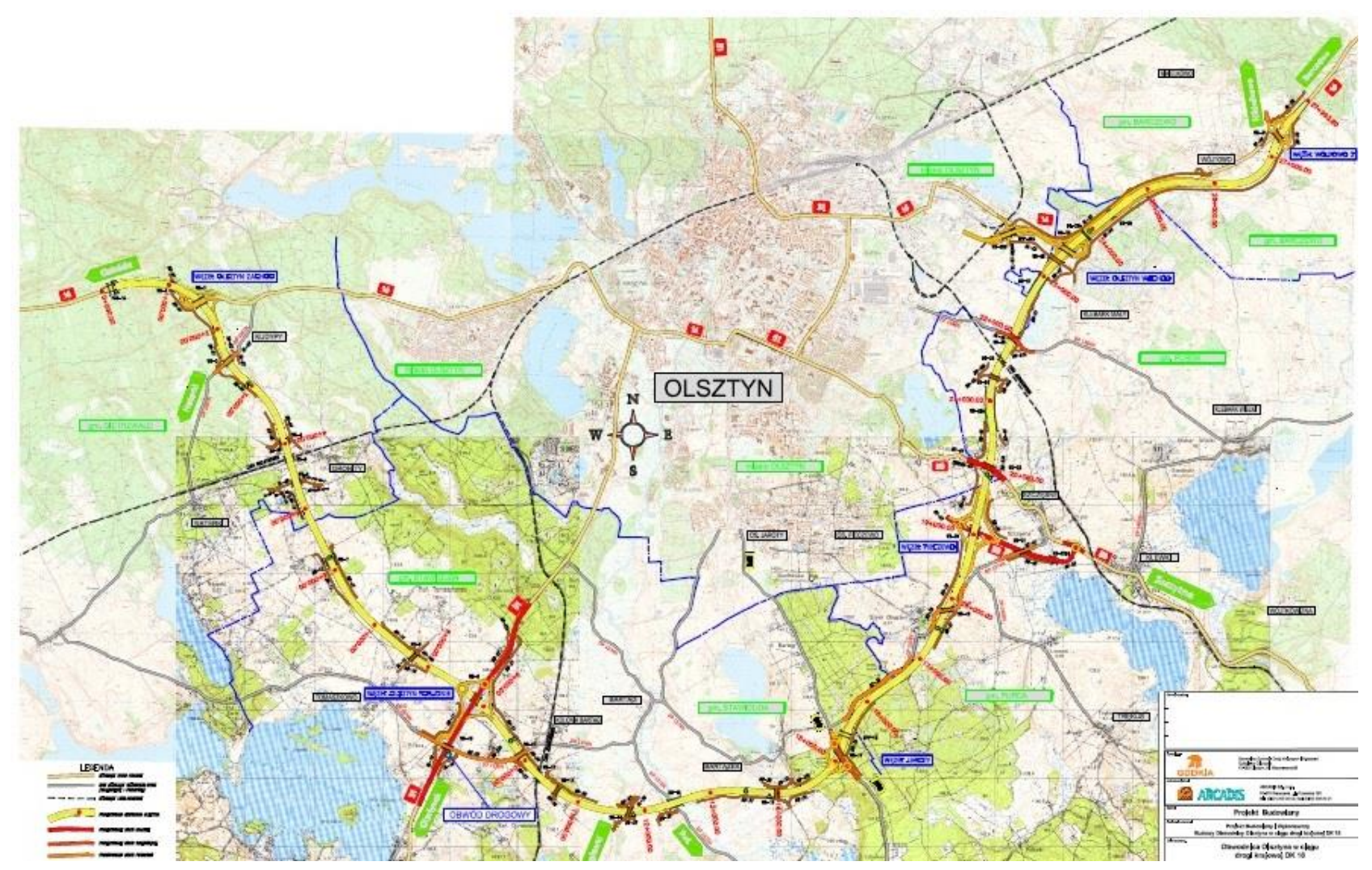

Fig. 1. The course of Olsztyn's southern ring-road (www.gddkia.gov.pl). 


\section{THE COURSE OF OLSZTYN'S SOUTHERN RING-ROAD TOWARDS FORMS OF NATURAL PROTECTION}

In the area of the planned construction of the southern ring-road, (...) impacts on the natural landscape will be among the most significant ones. A major part of the section planned for construction is located in a non-urbanised area. In the direct investment area, there are afforested lands, idle lands, wetlands, including low peatlands; the road will intersect two rivers: Łyna and the Szczęsne Canal (Streszczenie do..., 2011). Some sections of the ring-road will also run through legally protected areas or in their direct neighbourhood. The ring-road intersects areas such as:

- Area of Protected Landscape of the Pasłęka Valley,

- Area of Protected Landscape of the Middle Łyna Valley,

- Area of Protected Landscape of the Napiwodzko-Ramucka Forest. (Studium Uwarunkowań..., 2012)

In its initial course, the ring-road intersects the Area of Protected Landscape of the Pasłęka Valley. The overall length of this section is around $2.600 \mathrm{~m}$. The next section, which is around 1,500 m long, intersects the Area of Protected Landscape of the Middle Łyna Valley and the final section of around 8,200 m intersects the Area of Protected Landscape of the Napiwodzko-Ramucka Forest between Bartążek and Stary Olsztyn villages. In the neighbourhood of the ring-road, within the shortest distance of $450 \mathrm{~m}$, there is also the Area of Protected Landscape of the Olsztyn Lakeland. The Las Warmiński (Warmia Forest) nature reserve is also located at a distance of 2,400 $\mathrm{m}$ from the investment concerned, which means that it is not exposed directly to the negative impact of the investment.

A very important element of natural protection located in the route of the ring-road is the Special Bird Protection Area - the Napiwodzko-Ramucka Forest, which is a part of the Natura 2000 network, and the Special Protection Area - the Napiwodzko-Ramucka Refuge located $700 \mathrm{~m}$ away from the road. At the $3^{\text {rd }}$ kilometre of the ring-road, there is a natural monument close to it - a pedunculate oak located around $100 \mathrm{~m}$ away from the dividing line.

\section{ENVIRONMENTAL AND SPATIAL CONSEQUENCES OF THE LOCATION OF THE RING-ROAD}

The course of the road and its impact on the space and the environment arouses much controversy, particularly at the planning stage (Kowalczyk, Kil et al., 2014).

The Olsztyn ring-road project will certainly be a source of changes in the environment and space. These changes will be a consequence of the spatial location of the ring-road, as well as emissions of noise, gas substances, sewage and waste to the environment. The completion and use of the project may affect negatively the natural environment, the earth, landscape or climate.

One of the most important stages of construction of the ring-road will be a bridge over the Lyna River. Its length is $246 \mathrm{~m}$, and its height is $13 \mathrm{~m}$ at the lowest point of the valley. The presence of such a large structure in the landscape will determine a new landscape landmark in the viewing axis towards the valley of the Łyna River. Another distinguishing feature of the landscape can be the overpass over the Bagno Klebarskie reed field (length of $300 \mathrm{~m}$, height of $10 \mathrm{~m}$ at the lowest point of the valley).

Apart from that, the course of Olsztyn's ring-road collides with the following protected areas:

- Area of Protected Landscape of the Pasłęka Valley - collision area: 27 ha,

- Area of Protected Landscape of the Middle Łyna Valley - collision area: 11 ha,

- Area of Protected Landscape of the Napiwodzko-Ramucka Forest - collision area: 93 ha,

- Special Bird Protection Area - the Napiwodzko-Ramucka Forest (Natura 2000 area) - collision area: 31.4 ha. The investment is designed at the edge of the extensive Natura 2000 area (maximum $1 \mathrm{~km}$ into the Refuge) and cuts off extreme areas from the remaining territory of the Refuge, but the size and location does not have a significant impact on the benefits of this Special Bird Protection Area (Streszczenie opracowania..., 2013).

In connection with the construction of the road, there is a plan to cut 2.845 pcs of individual trees, multi-trunk trees or trees growing in dense groups and around 33.5 ha of managed forest.

'The green project' assumes plantings of 4.313 pcs of deciduous trees, 1043 pcs of coniferous trees and 706 pcs of climbing plants. In addition, plantings of a large number of shrubs are marked on the project maps. The green project under analysis assumes plantings of appropriately selected and arranged new trees and shrubs and the creation of lawns in dividing lines of the investments (apart from the road infrastructure) (Streszczenie opracowania..., 2013).

The types of soil prevailing in the investment area include brown soils with crude soils of good wheat, defective wheat, good rye and weak rye complexes. Apart from that, the area contains leached brown soils and acid brown soils of the soil complex no. 2 (good wheat complex) and 3 (defective wheat complex) as well as podsolic soils and rusty soils of the good wheat complex, good rye complex and very good rye complex. In addition, in the area of the end of the project from $21+200 \mathrm{~km}$, there are gley soils and black earths of the strong cereal-fodder complex and peat soils and muck-peat soils of the good wheat complex. The arable land occurring in the area concerned contains soils of the following valuation classes: IIIa (good arable soils), IIIb (average-good arable soils), IVa (average arable soils of better quality), IVb (average arable soils of worse quality), V (weak arable soils), VI (weakest arable soils), VIRZ (soils for afforestation) (Raport o oddziaływaniu ..., 2014).

The investment does not collide with structures and areas entered into the register of monuments of the Warmia and Masuria province. However, it collides with objects of religious cult, such as roadside shrines and crosses, which will be transferred to new locations upon arrangement with their owners already at the stage of construction of the ring-road.

Other objects colliding with the analysed route are 24 archaeological sites. 
The course of the ring-road has also an impact on the spatial arrangement of farms. The separation of land from sites, the worsened arrangement of plots or their shape may contribute seriously to a decrease of productivity in farms (Bacior, Harasimowicz, 2005). In his analysis, Bacior states: 'The construction of the motorway certainly affects the agricultural space, which results in losses with regard to agricultural land. The basis for the determination of losses is the analysis of the variability of the use of lands and soil evaluation classes and the arrangement of access roads to lands along the axis of the motorway under design' (Bacior, 2012). This statement can also be referred to the ring-road under analysis.

\section{CONCLUSIONS}

In spite of the length of $28 \mathrm{~km}$, the southern ring-road of Olsztyn has a relatively low impact on the environment. The heaviest environmental losses can be indicated in the valley of the Łyna River, in the Area of Protected Landscape of the Pasłęka Valley and in the area of the Bagno Klebarskie reed field. Serious losses in the forest area will occur in the Area of Protected Landscape of the Napiwodzko-Ramucka Forest and in the Special Bird Protection Area - the Napiwodzko-Ramucka Forest, where no collision with bird nest protection zones was found.

Systems of passages for the migration of small, medium-sized and large mammals, amphibians and reptiles are considered to be sufficient. Shapes and dimensions of designed passages are consistent with recommendations contained in the source literature and internal regulations of GDDKiA.

In connection with the removal of trees from the ring-road strip, new plantings are planned in the course of road construction works in the form of deciduous and coniferous trees and shrubs.

The construction of the ring-road will result in the exclusion of the agricultural land strip from use and in a very limited local impact of the road on soils. The analysis of the structure and the intended use of lands proves that these are not high-category arable lands, although they are good for cultivation (Streszczenie opracowania..., 2013).

The emission of pollutants into the air due to the high intensity of vehicular traffic will not result in air pollution levels exceeding admissible limits and reference levels.

In order to protect inhabitants against noise and to protect structures and areas requiring sound protection, acoustic screens will be installed along the road. At the same time, the expansion of acoustic screens in the Wójtowo village is required for the purpose of ensuring the proper acoustic climate, because the existing screens will not be effective in the context of the increasing intensity of traffic.

The course of the route of Olsztyn's southern ring-road is the best of all variants considered during planning works. It gives the possibility of expansion and spreading of the city in the southern direction. The future of dynamically developing housing estates is not endangered, and a large resource of lands for single- and multi-family housing is ensured. Inhabitants will have very good access to recreation \& leisure areas, including the Bartąg Lake.

The likelihood of a serious social conflict resulting from the construction of the ring-road should be regarded as low, because the choice of this course of the route was also supported by the local community.

\section{REFERENCES}

1. Bacior, S. 2012. Oddziaływanie autostrady na grunty rolne na przykładzie odcinka Brzozówka-Nowa Jastrząbka. ACTA Scientiarum Polonorum, Administratio Locorum, Vol 11, pp. 5-14. (In Polish)

2. Bacior, S., Harasimowicz, S. 2005. Odziaływanie autostrady na przydatność rolniczą gruntów i ich wartość na przykładzie odcinka autostrady A-4 między Brzeskiem a Tarnowem. Proceedings of the International Scientific Conference „Geodezja, kartografia i aerofotogrametria", Wydawnictwo Politechniki Lwowskiej, Vol. 66, pp. 9-19. Lwów, Ukraina. (In Polish)

3. Gwiaździńska-Goraj, K, Kurowska, K. 2011. Lokalizacja obwodnicy Olsztyna a obszary objęte ochroną: Czasopismo techniczne, Vol. 17, pp. 259-263. (In Polish)

4. Kowalczyk, K., Kil, J., Dudzińska, M., Kocur-Bera, K. 2014. Evaluation of spatial structure deterioration of land plots caused by a nearby motorway, based on a selected example using GIS tools. Proceedings of the International Scientific Conference „International Conference on Traffic and Transport Engineering”, pp. 642-651, ICTTE, Belgrade, Serbia.

5. Raport o oddziaływaniu przedsięwzięcia na środowisko. Streszczenie, 2014. (In Polish)

6. Streszczenie do „Raportu oddziaływania na środowisko” południowej obwodnicy Olsztyna, 2011. (In Polish)

7. Streszczenie opracowania dotyczącego oddziaływań środowiskowych związanych z budową i późniejszą eksploatacją nowego odcinka drogi - obwodnicy południowej Olsztyna w ciągu drogi krajowej nr 16, we wskazanym w decyzji środowiskowej wariancie II-niebieskim, 2013. (In Polish)

8. Studium Uwarunkowań i Kierunków Zagospodarowania Przestrzennego Gminy Stawiguda, część II, Kierunki zagospodarowania przestrzennego gminy, 2012. (In Polish)

9. www.gddkia.gov.pl (accessed on 18/05/2015) (In Polish)

10. www.obwodnica.olsztyn.eu (accessed on 18/05/2015) (In Polish) 